\title{
Occurrence and distribution of Kumaun Himalayan aquatic hyphomycetes: Lemonniera
}

\author{
Sati SC ${ }^{1}$, Pathak $\mathbf{R}^{1}$ and Belwal $\mathbf{M}^{2}$ \\ ${ }^{1}$ Department of Botany, Deb Singh Bisht Campus, Kumaun University, Nainital-263002, India \\ ${ }^{2}$ Department of Botany, Government Post Graduate College, Gopeswar, Uttrakhand, India
}

Sati SC, Pathak R, Belwal M 2014 - Occurrence and distribution of Kumaun Himalayan aquatic hyphomycetes: Lemonniera. Mycosphere 5(4), 545-553, Doi 10.5943/mycosphere/5/4/7

\begin{abstract}
Five species of aquatic hyphomycetes belonging to the genus Lemonniera (L. alabamensis, $L$. aquatica, L. cornuta, L. pseudofloscula and L. terestris) collected from different submerged leaf litter and water foam accumulated in fast flowing fresh water bodies of Kumaun Himalaya, (India) are described. The taxonomic description, occurrence and worldwide distribution of each recorded species along with a simplified key are also provided.
\end{abstract}

Key words - freshwater fungi - water foam - submerged leaf litter - taxonomy

\section{Introduction}

While describing four new species of aquatic fungi imperfectii from his algal collection de Wildeman (1894) also erected a genus Lemonniera in honour of Lemonnier, Professor of Botany at Nancy, France and L. aquatica, was the first species found on submerged leaves in fresh water bodies having peculiar tetraradiate phialidic conidia. Since these fungi abundantly occur on dead decaying submerged leaf litter of various deciduous trees in well aerated fresh water bodies, Ingold (1942) in his pioneering work named them aquatic hyphomycetes. Here described L. aquatica in pure culture isolated from submerged leaves of Alnus glutinosa in a stream of Leicestershire, England and the type species was further characterized. Ingold (1942) also established the phialidic nature of the conidiogenous cells, with exogenous development of the primordium, late appearance of the basal septum, followed by its cleavage at release, and successive basipetal proliferation. It was later confirmed by Ranzoni (1953) as four conidial arms are always well developed and arise from a primordium at the tip of a phialide.

Till 1977, this genus includes five species characterized by phialidic conidiogenus cells, and typically tetraradiate conidia with branches arising more or less simultaneously from a globose primordium just above the collarette of philiade (Descals et al. 1977). After two years one more species was added to this named L. alabamensis (Sinclair \&Jones 1979). Though a large number of aquatic hyphomycetes have been explored from different part of the world by various investigators (Alasoadura 1968; Descals \& Webster 1982; Hudson \& Ingold 1960; Ingold1975; Kuthubutheen 1987; Kuthubutheen et al. 1992; Marvanova 1997; Nawawi 1975, Nilsson 1964; Park 1974; Peterson 1962, Ranzoni 1953; Tubaki 1957; Webster \& Descals 1979), it is noteworthy that Sati and his coworkers also made a substantial contribution towards the aquatic hyphomycetes flora from Kumaun Himalaya, India (Sati et al. 2009, Sati \& Tiwari 1990, 1992, 1993, 1997; Tiwari \& 
Sati 1991, 1992). Kumaun Himalaya is located in the outer Central Himalaya $28^{\circ} 44^{\prime}$ to $30^{\circ} 49^{\prime} \mathrm{N}$ Lat. and $78^{\circ} 45^{\prime}$ to $81^{\circ} 1^{\prime} \mathrm{E}$ Long. India. It comprises of a temperate hilly zone, ranging $5-15^{\circ} \mathrm{C}$ temperature in winter while $20-30^{\circ} \mathrm{C}$ during summer having monsoon pattern of rainfall.

In the present study five species of aquatic hyphomycetes and two unknown conidia belonging to the genus Lemonniera from Kumaun Himalaya, India are described with their taxonomic details and worldwide distribution.

\section{Materials \& Methods}

For the present study, samples of dark decaying submerged plant material especially leaf litter and water foam accumulated at the barrier of fast flowing fresh water bodies were collected in sterile polythene bags and plastic vials from different high altitude fresh water unpolluted streams (1000-2000 m asl) viz, Jeolikote, Dogaon, Gufamahadev, Khurpatal, Kaichidham and Ramgarh of Kumaun Himalaya (India) time to time. The collected leaf litter was washed thoroughly under running tap water for 4-5 hours to remove planktons, soil particles and other extraneous material. The leaf litter was then cut into small pieces $(4-5 \mathrm{~cm})$ and placed into pre sterilized Petri dishes containing $20 \mathrm{ml}$ of sterile water for incubation at $15 \pm 2^{\circ} \mathrm{C}$. After $2-3$ days the incubated leaves were periodically examined under the microscope to detect the conidia of aquatic hyphomycetes. Conidia were picked aseptically and placed onto $2 \%$ MEA agar plate for culture at $15 \pm 2^{\circ} \mathrm{C}$ for 7 to 10 days. A piece of agar block containing fungal hyphae was cut and transferred in to a Petridish containing sterile water for sporulation. The observations of morphological characters of conidia present were recorded and identification was made with the help of available literature.

The collected water foam samples were fixed in 5\% FAA on the spot to avoid conidial germination and examined directly under the microscope by placing drop by drop on a glass slide. Semi-permanent slides of these conidial fungi have been deposited in the Kumaun University Mycological Slide (KUMS) collection at the Department of Botany, Nainital.

\section{Results}

A number of conidia were found growing on submerged leaf litter and foam collected from water bodies of Kumaun Himalaya, India. Some of the conidia were typically phialidic and tetraradiate which were identified as the species of Lemonniera. Altogether five species of Lemonniera (L. alabamensis, L. aquatica, L. cornuta, L. pseudoflosculaand L. terestris) have been recorded from various localities of Kumaun Himalayan streams. It is interesting to note that Kumaun Himalaya, India represent nearly $70 \%$ of the world known species of Lemonniera. Detailed taxonomic description and worldwide distribution of each recorded species along with a simplified key is provided here under (Fig. Plate1).

\section{Lemonniera de Wild.}

Submerged aquatic fungus with branched septate mycelium. Conidiophore consisting of a straight, unbranched portion which branches near its free end to form a group of two to eight phialides. Each phialide produces conidia in basipetal succession. Conidium consisting of four long divergent arms (which usually become septate), 20-70 $\mu \mathrm{m}$ long, 3-4 $\mu \mathrm{m}$ broad and inserted on the phialide at the point of divergence of the four arms of the conidium.

Lemonniera alabamensis R.C. Sinclair \& Morgan Jones

(Fig. 2 g, h, Plate $1 \mathrm{C}$ )

Submerged aquatic fungus with hyaline branched septate mycelium. Conidiophore 52.6-60 $\mu \mathrm{m}$ long and 3-4 $\mu \mathrm{m}$ wide, hyaline, erect septate simple or more commonly irregularly branched at upper part and bearing phialidic cells, 9-12 $\mu \mathrm{m}$ long and 3-4 $\mu \mathrm{m}$ wide upon which conidium develop. Conidia hyaline with very distinct spherical central body, $3-5 \mu \mathrm{m}$ in diameter and consisting of 4 divergent branches, 33-45 × 3-3.38 $\mu \mathrm{m}$.

This species was recorded from Ramgarh, Kumaun Himalayan stream. Earlier it was recorded from Jageshwar stream on decaying submerged leaf litter of Polygonum nepalensis and Nerium sp. 
It was found as a new record for Indian aquatic fungi (Sati et al. 2002). The present isolate resembles to Sinclair \& Morgan Jones (1979) but differs in absence of septa in arms.

Geographical Distribution - It appears to be a restricted species of Lemonniera. Earlier it has been reported from Brazil (Fiuza \& Gusmao 2013), Europe (Menendez et al. 2012); India (Sati et al. 2002), North America (Sinclair \& Morgan 1979).

Lemonniera aquatica de Wildeman

(Fig.1 a, b; Plate 1 B)

Submerged aquatic fungus with branched hyaline mycelium. Conidiophore long, septate hyaline, erect, simple and conidiogenous cells are phialidic present on conidiophores. Conidia developed on phialidic cells consisting of four divergent branches. Conidial primordium immediately branch directly above the tip of phialidic cells into typically four arms which diverge tetrahedrally one arm always distal and rest growing slightly backwards. Conidial arms 35-44.7 $\times$ 2.8-3.5 $\mu \mathrm{m}$, non-tapering and septate.

This species was first recorded from Sat Tal (Mer \& Khulbe 1981) and then was also collected from Jageshwar stream. Isolated from water foam samples and submerged decaying leaf litter of Nerium sp. In the present study it was recovered from Ramgarh stream in October 2013 from unknown leaf litter. This isolate is very much similar to the species described by Descals et al. (1977) but slightly shorter than the species described by Marvanova (1997).

Geographical Distribution - It is one of the most commonly occurring species reported from various part of the world showing its wide distribution. Australia (Cowling \& Waid 1963), Berlin (Bauman \& Poelt 1970), Canada (Barlocher \& Kendrick 1974), Central America (Santos \& Betancourt 1997), Czech Republic (Marvanova 1997), England (Ingold 1960, Iqbal \& Webster 1973), France (de Wildeman 1894, 1895), Germany (Arnold 1968, 1970), Hungry (Gonczol 1971), India (Mer \& Khulbe 1981), Japan (Tubaki 1957), Norway (Nilsson 1964), Poland (Nilsson 1964), Romania (Toth 1973), South Africa (Greathead 1961), Spain (Roldan et al. 1987, Roldan \& Honrubia 1990, Descals \& Moya 1996), USA (Dyko \& Tiffany 1972, Ranzoni 1953, Peterson 1963).

Lemonniera cornuta Ranzoni

(Fig.1 c, d, Plate 1 A)

Submerged aquatic fungus with branched septate mycelium. Conidiophores hyaline, erect, penicilliod consisting of an unbranched basal portion bearing a number of bottle shaped phialides, $12.5 \times 3.15-3.75 \mu \mathrm{m}$. Conidial primordium initially spherical, later appearing as inverted tetrahedron which soon becomes flattenedand develops into four growing points at right angle to each other. Mature conidia consist 4 divergent arms with an indistinct central body. Septa indistinct before release but later on several septa may appear per arm. Arms 20-50 (mainly 30-40) × 3.75-5 $\mu \mathrm{m}$. Each pair of branches curved in opposite direction inserted on the phialides at the point of divergence, attached at right angles to the longitudinal axis of phialide.

It is one of the most commonly occurring species as it occurred in all study sites in July to September. It was earlier reported from freshwater streams of Kumaun Himalaya (Tiwari \& Sati 1991) and as root endophyte from Kumaun Himalaya (Sati \& Belwal 2005). This isolate was found very much similar to the species described by Ranzoni (1953) as well as Descals et al. (1977).

Geographical Distribution - Central America (Santos \& Betancourt 1997),UK (Iqbal 1972 a, b, Iqbal \& Webster 1973), India (Tiwari \& Sati 1991, Sati \& Belwal 2005), Japan (Miura 1967, 1974), Spain (Descals \& Moya 1996), Russia (Dudka 1973, 1974), USA (Ranzoni 1953, Peterson 1963).

\section{Lemonniera pseudofloscula Dyko}

(Fig. 1 g, h, Plate 1 E)

Submerged aquatic fungus with hyaline, septate branched mycelium. Conidiophores slightly branched to form a group of erect phialides. Conidial primordial initially spherical later become tetrahedral, 4-5 arms budding from central body. Conidia hyaline, tetrahedral with distinct sub spherical central body 4-5.2 $\mu \mathrm{m}$ in diameter. Arms 4-5 with constricted base, 29-34 × 4-5 $\mu \mathrm{m}$. Arm apices tapering with rounded apex, septa 2-5 per arm. 

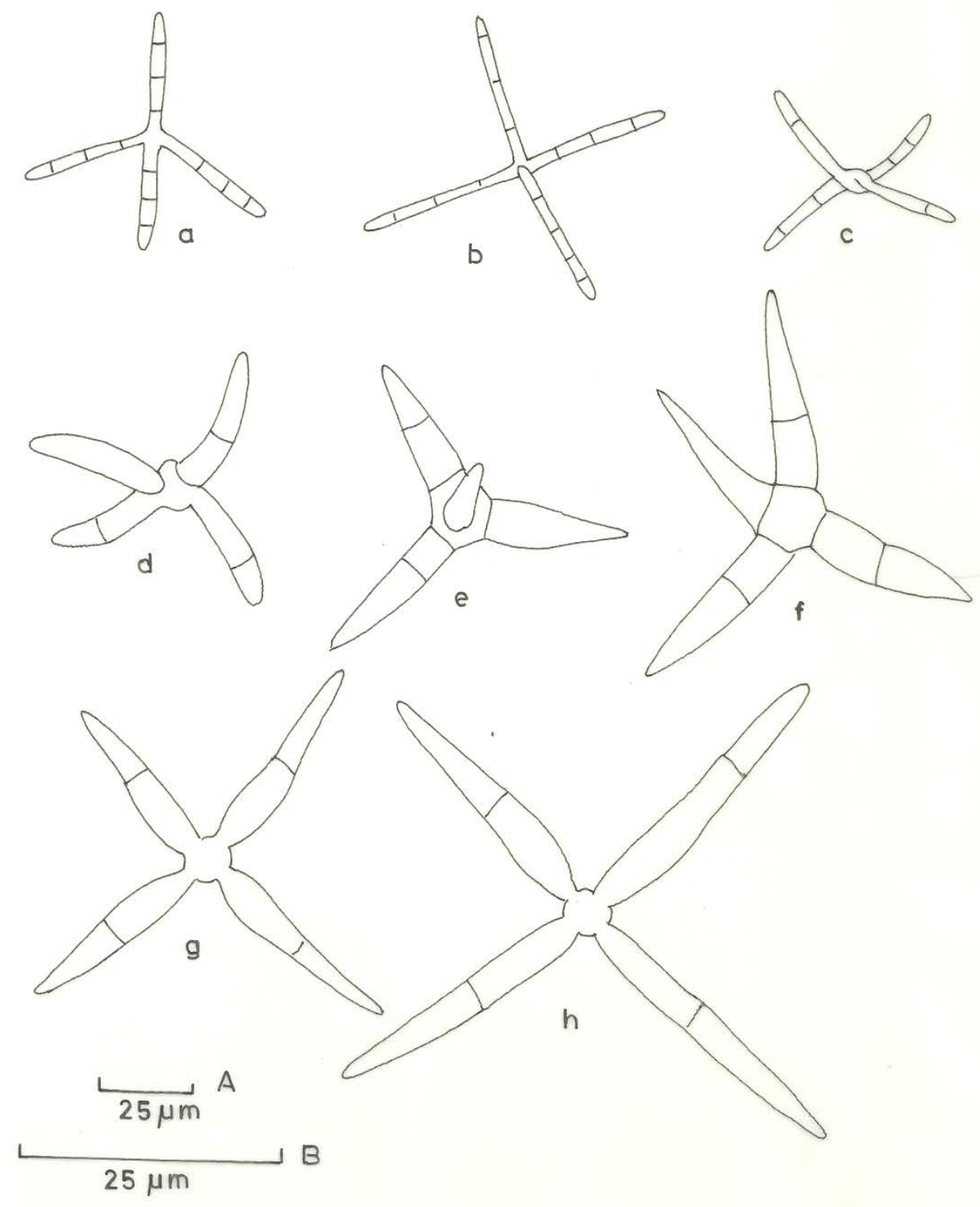

Figs 1. a, b-Lemonnieraaquatica; c, d-L.cornuta; e, f - L. terrestris; $\mathbf{g}, \mathbf{h}-$ L. pseudofloscula. (Fig a, b, cin Scale A and rest all in Scale B)

This species was collected from Ramgarh stream. Earlier it was reported from freshwater streams ofJeolikoteandJageshwarinKumaun Himalaya (Sati et al. 2002) and also as root endophyte of Lyoniaovalifolia (Sati \& Belwal 2005). The Kumaun Himalayan isolate L. pseudofloscula hasshorter conidial arms than the species described by Descals et al. (1977). The number of septa in Kumaun Himalayan isolate is 2-5 per arm while Descals et al. (1977) reported 7 septa in each arm.

Geographical Distribution - It is also appear to be one of the restricted species in distribution. Brazil (Fiuza \& Gusmao 2013), Central America (Santos-Flores \& Betancourt-Lopez 1997), Europe (Fabre 1998), India (Sati. et al. 2002, Sati \& Belwal 2005), North America (Descals et al. 1977).

\section{Lemonniera terrestris Tubaki}

(Fig. 1 e, f, Plate 1 D)

Submerged aquatic fungus with hyaline, branched, septate mycelium. Conidiophores erect, septate with simple or penicillate head. Phialides amupulli form, $15-40 \times 3-5 \mu \mathrm{m}$ in size. Conidial primordia spherical but soon branches out into typically four arms, which diverge tetrahedrally, one 
branch always turns upwards while in others radiating slightly backwards. Conidia hyaline, protoplasm pearly, central body absent or indistinct. Arms 3 to 5 (mostly 4) 16.5-20 $3.5 \mu \mathrm{m}$ tapering towards the apex and occasionally septate.

This species was found in Dogaon and Ramgarh streams. Earlier reported from Kumaun Himalayan freshwater streams (Sati et al. 2002 a, b) and also recorded as root endophyte of Lyonia ovalifolia (Sati \& Belwal 2005). In Kumaun Himalayan species arms are shorter than the species described by Descals et al. (1977) and arms are occasionally sepatate.

Geographical Distribution - This species show a wide distribution as it has been recorded from various part of the world. Australia (Tubaki 1965), Canada (Ingold 1960), Central America (Santos-Flores \& Betancourt-Lopez 1997), Cuba (Marvanova \& Marvan 1969), Czechoslavia (Marvanova \& Marvan 1963), England (Ingold 1958), Hungry (Gonczol 1971), India (Sati et al. 2002, Sati \& Belwal, 2005), Japan (Miura 1967, 1974), South Africa (Greathead 1961), Spain (Descals \& Moya 1996), Sweden (Nilsson 1962, 1964), U. S. A. (Nilsson 1964).
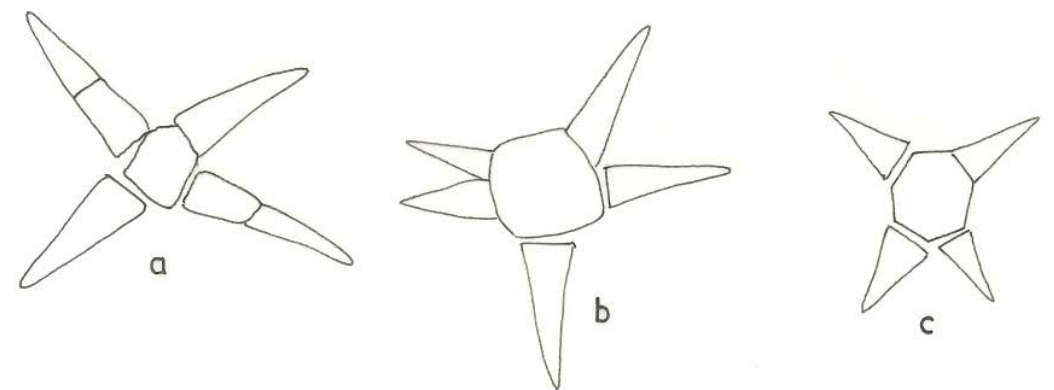

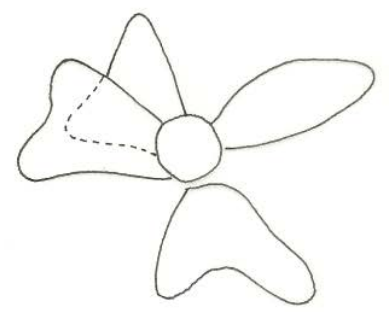

d

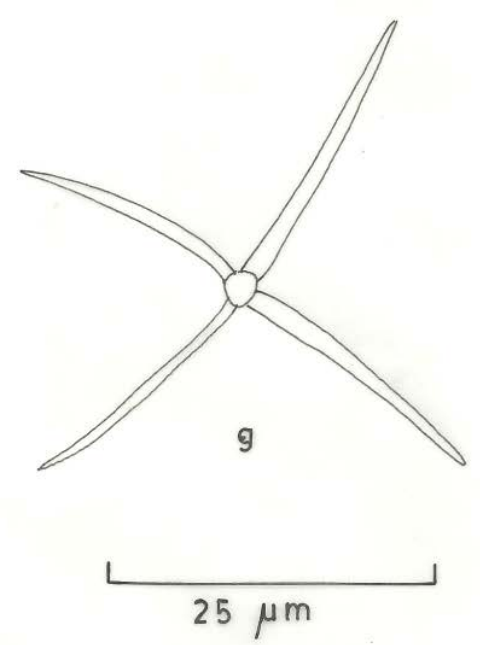

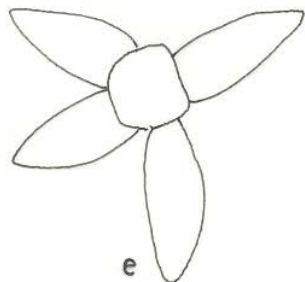
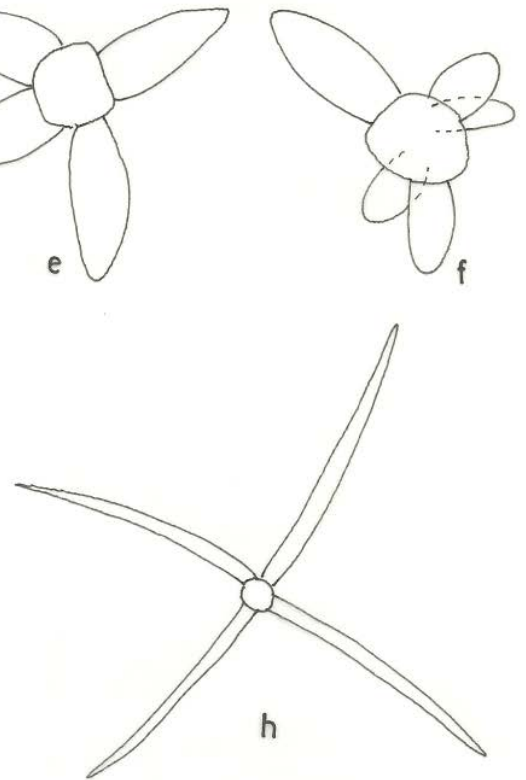

Figs. 2. a, b, c - Lemonniera sp. 1; d, e, f-Lemonniera sp. 2; g, h-L. alabamensis
(Fig. 2 a-c, Plate 1 F) 
Submerged aquatic fungus with branched sepatate, hyaline mycelium.Conidia with $3-(4)-5$ arms. Central body distinct, bulky, pentagonal or hexagonal, 5-10 $\mu \mathrm{m}$. Arms 6.25-20 $\mu \mathrm{m}$ long and 3.75-5 $\mu \mathrm{m}$ broad, taper acutely towards the apex having $0-1$ septum.

The conidia were collected from Niglat stream, Nainital Kumaun Himalaya, on submerged decaying leaf litters of Daphniphyllum himalayense in December, by Tiwari (1992).

These conidia appeared to be very close to L. terrestris but differed in size and distinct central body. On perusing the available literature these conidia did not fit to any known species. Since the conidia could not be cultured in 2\% MEA therefore, in absence of full cultural details it was retained as the unknown species of Lemonniera (Tiwari 1992).

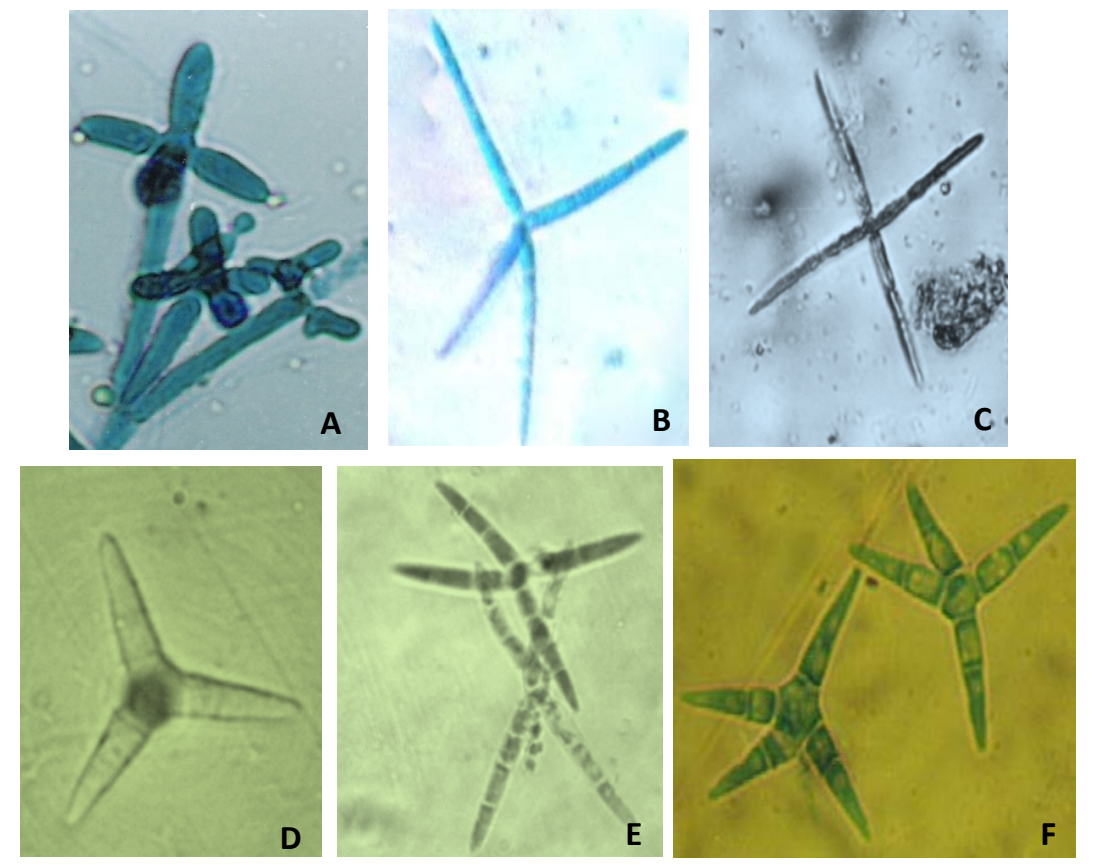

Plate 1. A - Lemonniera cornuta $(x=350), \mathbf{B}-$ L. aquatica $(\times=500), \mathbf{C}-$ L. alabamensis $(\times=$ 375), D - L. pseudofloscula $(x=430), \mathbf{E}-$ L. terrestris $(x=750), \mathbf{F}-$ Lemonniera sp 1. $(\times=500)$.

\section{Lemonniera sp. 2}

(Fig. $2 \mathrm{~d}-\mathrm{f}$ )

Submerged aquatic fungus with hyaline, branched septate mycelium. Conidia borne on ampulliform phialides developed on erect conidiophores. Conidia characterized by distinct central body 3.75-5 $\mu \mathrm{m}$ (occasionally 8.8-9.4 $\mu \mathrm{m}$ ). Arms 5, bulky, non septate, attached to the central body by isthmii, 10-15 × 5-7.5 $\mu \mathrm{m}$.

It was found growing on submerged decaying litter of Daphniphyllum himalayaense from snow view stream and water foam in September by Tiwari (1992).

These conidia were found close to L. pseudofloscula but the general look and conidial size including non septate bulky arms do not permit to include it in L. pseudofloscula and therefore, it was also tentatively kept under Lemonniera sp. 2 (Tiwari 1992).

\section{Key to the Kumaun Himalayan species of Lemonniera}

Conidia hyaline consist of usually four divergent branches inserted on a phialide at the point of

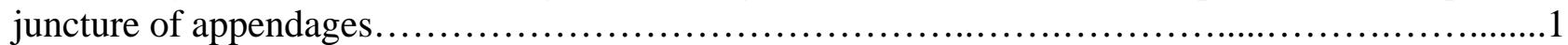

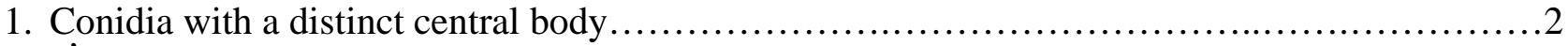

1 ' Conidia with indistinct central body or absent.............................................

2. Conidia with spherical central body. 3-5 $\mu \mathrm{m}$ in diameter with four divergent branches $33-45 \times$ 3-3.38 $\mu \mathrm{m}$ 
2.'Conidia with sub spherical central body 4-5.2 $\mu \mathrm{m}$ in diam. Arms slightly bulky, with constricted base and apices tapering end rounded apex measuring 29-34 $\times$ 4-5 $\mu \mathrm{m}$

L. pseudofloscula

3. Central body indistinct or absent.

3.'Central body is absent. Conidia consist of four arms diverge tetrahedrally, one arm always upward as main axis, rest arm growing slightly backward size 35-44.7 × 2.8-3.5 $\mu \mathrm{m}$ and nontapering.

.L. aquatica

4. Arms 3-5 tapering towards the apex, arms short $16.5-20 \times 3.5 \mu \mathrm{m}$, occasionally

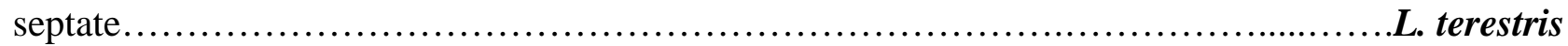

4.' Arms four divergent appeared as inverted tetrahedron which becomes flattened. Arms approximately of equal lengths with several septa measuring $30-40 \times 3.75-5$ $\mu \mathrm{m}$

L. cornuta

\section{Acknowledgements}

This work is supported by a grant from SAP (DRS) UGC, New Delhi. Thanks are also due to the Head, Department of Botany, Kumaun University, Nainital, India for providing lab facilities.

\section{References}

Alasoadura SO. 1968 - Some aquatic Hyphomycetes from Nigeria. Trans. Brit. Mycol. Soc, 51: 535-540.

Arnold GRW. 1968 - Sporen aquatischer Hyphomyzeten aus Gewaessern im bezirk Halle. Wissenschaftliche Zeitschrift der Friedrich-Schiller Universitaet Fena (MathematikNaturwissenschaft Reihe) 17, 369-373.

Arnold GRW. 1970 - Hyphomycetes aquatic ex aquariis regionis leningradensis isolate. Novosti Sistematik niz Kast Akademia Nauk. SSSR Botanicnyi institute 6, 176-189.

Barlocher F, Kendrick B. - 1974. Dynamics of fungal population on leaves in a stream. J. Ecol., 62: 761-791.

Baumann LH, Poelt J. 1970 - Wasserbewohnende Hyphomycetezen in Raum von Berlin. Verh \& lungen der Botanischen Vereins de Provinze Brandenburg 107, 65-79.

Cowling SW, Waid JS. 1963 - Aquatic Hyphomycetes in Australia. Australian Jour. Sci., 26: 122124.

De Wideman E. 1894 - Notes Mycologiques. Fascicle 3 Ann. Soc. Belge. Microsc., 18: 135-161.

De Wildeman E. 1895 - Notes Mycologiques. Fascicle 6 Ann Soc. Belge. Microsc., 19: 191-232.

Descals E, Webster J, Dyko BS. 1977 - Taxonomic studies on aquatic hyphomycetes. I Lemonniera de Wildeman. Trans. Brit. Mycol. Soc. 69 (1), 89-109.

Descals E, Webster J. 1982 - Taxonomic studies on "aquatic hyphomycetes” III some new species and a new combination. Tran. Brit. Mycol. Soc., 78: 405-437.

Descals E. Moya O. 1996 - Fungal spora from streams in the Catalene Pyrenees.Bol. Soc. Micol. Madrid. Spain.21:145-174.

Dudka IA. 1973 - Aquatic Hyphomycetes of the Ukraine. 1. New species for the mycoflora of the Soviet Union. Ukrainskii Zhurnal 30, 449-456.

Dudka IA. 1974 - Ukrainianaquatic Hyphomycetes. Academy of sciences of the Ukrainian R. S. R. M. G. Holodny Botanical institute. Publications 'NaukovaDumka', Kiev.

Dyko BJ, Tiffany LH. 1972 - A preliminary study of aquatic Hyphomycetes in Iowa. Proceedings of the Iowa Academy of Sciences.78, 72-73.

Fabre E. 1998 - Aquatic hyphomycetes in three rivers of southwestern France. II. Spatial \& temporal differences between species. Canadian Journal of Botany 76, 107-114.

Fiuza PO, Gusmao LFP. 2013 - Ingoldian fungi from the semi-arid Caatinga biome of Brazil, Mycosphere 4 (6): 1133-1150. 
Gonczol J. 1971 - Aquatic Hyphomycetes from the mountains Boerzsoeny. Annals of natural History of the National Museum of hungry 63, 57-75.

Greathead SK. 1961 - Some aquatic Hyphomycetes in South Africa. Journal of South African Botany, 27, 195-228.

Hudson HJ, Ingold CT. 1960 - Aquatic Hyphomycetes from Jamaica. Trans. Brit. Mycol. Soc., 73: 109-116.

Ingold CT. 1942 - Aquatic Hyphomycetes of decaying alder leaves. Trans. Brit. Mycol. Soc., 25: 339-417.

Ingold CT. 1958 - Aquatic hyphomycetes from Uganda \& Rhodesia. Trans. Brit. Mycol. Soc., 41: 109-114.

Ingold CT. 1960 - Aquatic Hyphomycetes from Canada. Can. J. Bot., 38: 803-806.

Ingold CT. 1975 - An illustrated guide to aquatic and water borne hyphomycetes (Fungi Imperfecti) with notes on their biology. Freshwater Biol. Assoc. Scient. Publ. No. 30, England, 96 pp.

Iqbal SH. 1972a - New aquatic Hyphomycetes. Trans. Brit. Mycol. Soc 59, 301-307.

Iqbal SH. 1972b - Some observations on aquatic Hyphomycetes.Ph. D. thesis, University of Exeter, England.

Iqbal SH, Webster J. 1973 - The trapping of aquatic hyphomycetes spores by air bubbles. Trans. Brit. Mycol. Soc., 60: 37-48.

Kuthubutheen AJ. 1987 - A new species of Phalangisporaand further observation on P. constricta from Malaysia. Trans. Brit. Mycol. Soc., 89: 414-420.

Kuthubutheen AJ, Liew GM, Nawawi A. 1992 - Nawawia nitida anam. Sp. Nov (Hyphomycetes) and further records of Nawawiafilliformis from Malaysia. Can. J. Bot., 70: 96-100.

Marvanova L. 1997 - Freshwater hyphomycetes: A survey with remarks on tropical taxa. In Tropical Mycology (eds. K. K. Janardhanan, C. Rajendran, K. Natrajan\& D. L. Hawksworth) Science Publishers Inc., 169-226.

Marvanova L, Marvan 1963 - Einige Hyphomyzetenaus den Fliessenden Gewassern des HrubyJesenik.Acta Musei Silesiae.Opawa (C. S. S. R.) (ser.A) 12, 101-108.

Marvanova L, Marvan 1969 - Aquatic Hyphomycetes in Cuba. Ceska Mycologie.23, 135-140.

Menendez M, Descals E, Riera T, Moya O. 2012 - Effect of small reservoirs on leaf litter decomposition in Mediterranean headwater streams, Hydrobiologia 691, 135-146.

Mer GS, Khulbe RD. 1981 - Aquatic Hyphomycetes of Kumaun Himalaya, India. Sydowia, Annales Mycologic., 34: 118-124.

Miura K. 1967 - An annotated list of Aquatic Hyphomycetes of Sugadaira, Japan. Trans. Mycol. Soc. Japan 8, 23-27.

Miura K. 1974 - Stream spora of Japan. Trans. Mycol. Soc. Japan. 15, 289-308.

Nawawi A. 1975 - Triscelophorous acuminatus sp. nov. Trans. Brit. Mycol. Soc., 64: 345-348.

Nilsson S. 1962 - Second note on Swedish freshwater Hyphomycetes. Botaniska Notiser 115, 7386.

Nilsson S. 1964 - Fresh water Hyphomycetes. Taxonomy, Morphology and Ecology.Symb. Bot. Upsal., 18: 1-30.

Park D. 1974 - Aquatic hyphomycetes on non-aquatic habitats.Trans. Brit. Mycol. Soc., 63: 183187.

Peterson RH. 1962 - Aquatic Hyphomycetes from North America. I Aleuriosporae (Part I) and key to genera.Mycologia, 54: 117-151.

Peterson RH. 1963 - Aquatic Hyphomycetes from North America II Aleuriosporae (Part II) and Blastosporae. Mycologia, 55: 18-29.

Ranzoni FV.1953 - The aquatic hyphomycete of California. Farlowia, 4: 353-398.

Roldan A, Descals E, Honrubia M. 1987 - Aquatic Hyphomycetes in the upper basins of the rivers Segura and Guadalquivir (South Spain). Anals DE Biologia.13: 3-13.

Roldan A. Honrubia M. 1990 - Aquatic Deuteromycetes in the Province of Alincate (Spain). Bol. Soc. Micol. Madrid. 14: 21-42. 
Santos-Flores C, C Betancourt-Lopez. 1997 - Aquatic and water-borne Hyphomycetes (Deuteromycotina) In streams of Puerto Rico (including records from other Neotropical locations).Carib. J. Sci., Special Publication, 2: 116.

Sati SC, Tiwari N. 1990 - Some aquatic Hyphomycetes of Kumaun Himalaya, India. Mycotaxon, 39: 407-414.

Sati SC, Tiwari N. 1992 - Colonization, species composition \& conidial production of aquatic hyphomycetes on chir pine needle litter in fresh water Kumaun Himalayan stream. Int. Revue. Ges. Hydrobiol., 77: 445-453.

Sati SC, Tiwari N. 1993 - A new species of Pestalotiopsis on submerged leaf litter. Nova Hedwigia, 56: 543-547.

Sati SC, Tiwari N. 1997 - Glimpses of conidial aquatic fungi in Kumaun Himalaya. In "Recent Researches in Ecology, Environment and pollution” X: 17-37. Eds. S.C.Sati, J. Saxena\& R.C. Dubey.Today and Tomorrow printers and Publishers, New Delhi, India.

Sati SC, Tiwari N, Belwal M. 2002 a - Species Diversity of water borne conidial fungi in running freshwater bodies of Kumaun Himalaya, Uttaranchal. In: Microbial Diversity, Status and Potential Applications. Eds. S. C. Tiwari \& G. D. Sharma. PP. 26-35.

Sati SC, Tiwari N, Belwal M. 2002 b - Conidial aquatic fungi of Nainital, Kumaun Himalaya, India. Mycotaxon, 81: 445-455.

Sati SC, Belwal M. 2005 - Aquatic hyphomycetes as endophyte of riparian plant roots. Mycologia, 97: 45-49.

Sati SC, P Arya, Belwal, M. 2009 - Tetracladium nainitalense sp. Nov. a root endophyte from Kumaun Himalaya, India. Mycologia 101 (5), 692-695.

Sinclair HI, Morgan Jones G. 1979 - Notes on hyphomycetes. 32. Five new aquatic species. Mycotaxon 9 (2), 469-481.

Tiwari N, Sati SC. 1991 - Contribution to Indian aquatic hyphomycetes. Two new additions. Acta Botanica Indica, 19: 256-258.

Tiwari N. 1992 - Taxonomy and species composition of Hyphomycetes in forested streams and their colonization pattern on tree leaves in Nainital, Central Himalaya, Ph. D. Thesis, Kumaun University, Nainital, India.

Tiwari N, Sati SC. 1992 - Two notable additions to Indian aquatic hyphomycetes. Nat. Acad. Sci. Lett., 15: 31-32.

Toth 1973 - Aquatic Hyphomycetes from Transylvania. Botanikai Koezlemenyek 60, 153-156.

Tubaki K. 1957 - Studies on Japanese Hyphomycetes III Aquatic group. Bull. Nat. Sci. Mus. Tokyo, 41: 294-268.

Tubaki K. 1965 - Contribution towards the fungus flora of Australia and New Zealand. Annual report of the institute of fermentation, Osaka 2, 39-62.

Webster J, Descals E. 1979 - The teleomorph of water-borne Hyphomycetes from fresh water. In "The Whole Fungus" Vol. 2 (B. Kendrick, Ed.) Ottawa, National Museum of Canada \& Kananaskis Foundation. 419-451. 